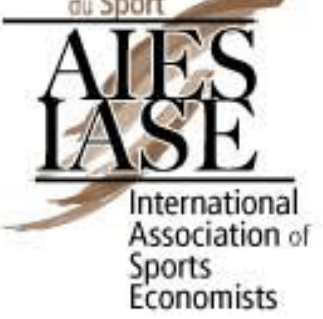

IASE/NAASE Working Paper Series, Paper No. 07-21

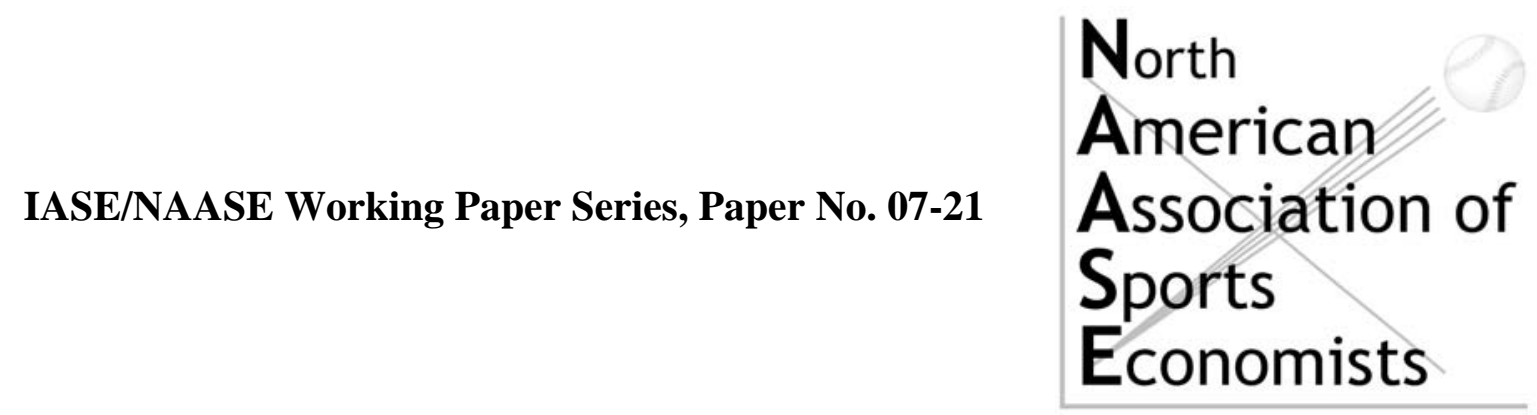

\title{
Short-term to long-term employment effects of the Football World Cup 1974 in Germany
}

\author{
Florian Hagn and Wolfgang Maennig ${ }^{\dagger}$
}

June 2007

\begin{abstract}
This study demonstrates that the Football World Cup 1974 in Germany was not able to generate any short to long-term employment effects that were significantly different from zero. It is the first work to examine long-term employment effects of Football World Cup tournaments. It is also one of the first work to undertake a multivariate analysis of the employment effects of a major sporting event outside of the USA. In addition, this study does not arbitrarily determine the time period for the potential positive effects of a major sporting event but instead examines several alternative periods. Furthermore, the study tests for method sensitivity by analysing the data set in parallel with the approaches used in the studies of sporting events in the USA as well as in a fourth modifying estimation approach. In contrast to the conclusions reached in comparable studies, the results are not regarded as a clear refutation of the positive effects of major sporting events.
\end{abstract}

JEL Classification Codes: L83, R53, R58

Keywords: Labour market, regional economics, sports economics, World Cup, Stadium Impact

This paper is also available as University of Hamburg Working Paper Series in Economic Policy, Number 09/2007.

†University of Hamburg, Chair for Economic Policy, Von-Melle-Park 5, 20146 Hamburg, Germany, E-mail: maennig@econ.uni-hamburg.de, phone: +49 (0)40 42838 - 4622, fax: +49 (0)40 42838 - 6251 
Florian Hagn, Wolfgang Maennig*

\title{
Short-term to long-term employment effects of the Football World Cup 1974 in Germany
}

\begin{abstract}
This study demonstrates that the Football World Cup 1974 in Germany was not able to generate any short to long-term employment effects that were significantly different from zero. It is the first work to examine long-term employment effects of Football World Cup tournaments. It is also one of the first work to undertake a multivariate analysis of the employment effects of a major sporting event outside of the USA. In addition, this study does not arbitrarily determine the time period for the potential positive effects of a major sporting event but instead examines several alternative periods. Furthermore, the study tests for method sensitivity by analysing the data set in parallel with the approaches used in the studies of sporting events in the USA as well as in a fourth modifying estimation approach. In contrast to the conclusions reached in comparable studies, the results are not regarded as a clear refutation of the positive effects of major sporting events.
\end{abstract}

Keywords: Regional economics, sports economics, World Cup, Stadium Impact JEL classification: L83, R53, R58

Version: June 2007

\section{Introduction}

Measured in terms of television and stadium spectators, the Football World Cup, together with the Olympic Games, represents the largest sporting event of our time. Every four years numerous nations apply to host the event, hoping as they do for positive political, psychological, sociological, cultural and economic effects (cf. Ritchie and Yangzhou, 1987 for the Olympic Games). The last-mentioned economic advantages appear to be particularly tangible in the form of income and employment effects and for this reason often form the focus of the applicants' argumentation. Ex-ante studies on the

University of Hamburg, Faculty Economics and Social Sciences, Department of Economics and Business Administration. Von-Melle-Park 5, 20146 Hamburg, Germany. E-mail: maennig@econ.unihamburg.de. Phone: +49 (0)40 42838 - 4622. Fax +49 (0)40 42838 - 6251. 
World Cup that examine this kind of effect can be found in Goodman and Stern (1994), Rahmann et al. (1997); Ahlert (2000); Khoza (2000) or Grant et al. (2003).

An ex-post study of the income and employment data of a Football World Cup on an econometric basis has so far only been undertaken by Baade and Matheson (2004). In order to test the effects of the 1994 World Cup held in the USA, they use data on 73 metropolitan areas representing the largest MSAs in the US by population over the time period 1970-2000 to estimate income growth for host cities for each year from 1970 to 2000. The predicted income growth is then compared to the actual income growth that each MSA experienced in 1994. They also take into account both those trends and developments that affected all host cities equally, as well as developments specific to individual cities. They come to the conclusion that the actual growth for 1994 in most host cities diverges negatively from the growth thus modelled. 9 of the 13 host cities suffered declines in growth. Overall the 13 locations suffered losses on balance of over US\$ 9 billion. ${ }^{1}$ Hagn and Maennig (2007) analyse the short-term effects of the World Cup 2006 and do not find any significant effects. This kind of pessimism is in evidence not only for the Football World Cup, but by and large in many multivariate econometric studies relating to other major sporting events or venues. The majority of these studies suggest that the sporting events or sports stadia have little or no significant impact on regional income and/or employment (e.g. Baade (1987); Baade and Dye (1990); Baade (1994); Baade and Sanderson (1997); Baade and Matheson (2000, 2001, 2002)). A number of works, particularly those of Coates and Humphreys (1999, 2000a and b, 2002, 2003a and b) or Teigland (1999), even arrive at significant negative effects.

To our knowledge, only very few studies find significant positive effects of sport facilities and sport events ex post. Baim, (1994) finds positive employment effects for Major

1 On ex-post World Cup analyses on the basis of questionnaires cf. Kim and Patrick (2005) who analyse Seoul residents' perceptions on impacts of the 2002 World Cup. They find that three months after the event, "World Cup fever became diluted" (p. 37). Kim, Gursoy and Lee (2006) also arrive at unsatisfactory perceived economic results for Korea 2002, but by contrast to satisfactory cultural results. Stadium costs, which were perceived as high, are explained via social exchange theory in connection with the economic benefits, perceived as unsatisfactory. Szymanski (2002) collects data on the twenty largest economies measured by current GDP over the last thirty years, many of which have hosted the Olympic Games or the World Cup at least once during that period. Using a simple regression he comes to the conclusion that the growth of these countries was significantly lower in the years where they organised World Cups or Olympic Games. 
League Baseball and Football for 15 cities in the USA. Kang and Perdue (1994) use a simple regression to find that the Olympic Games of Seoul 1988 led to 1 million additional arrivals and US\$ 1.3 billion additional income from tourism in Korea. Hotchkiss et al. (2003) find significant positive employment effects on regions in Georgia (USA) affiliated or close to Olympic activities of the Atlanta Olympic Games in 1996, but they did not find significant wage effects. Tu (2005) finds significant positive effects of the FedEx Field (Washington) on real estate prices in its neighbourhood as do Ahlfeldt and Maennig (2007a, b) for three arenas in Berlin (Germany). Finally, Carlino and Coulson (2004) examine the 60 largest MSAs in the USA and find that having a NFL team makes the cities "enjoy" rents which are 8 percent higher ${ }^{2}$ - but wages which are not higher. $^{3}$

The present work supplements previous publications in a number of respects. It is the first work that examines the long-term employment effects of World Cup tournaments on a multivariate basis. It is the first multivariate work that examines the employment effects of a major sporting event outside of the USA. This is particularly interesting set against the background of the different modes of functioning of the labour markets in the USA and Europe. It is also the first work which does not determine the time frame for the potential positive effects of a major sporting event in a more or less arbitrary

2 Many non-economists would interpret such rents as a case against sports. By contrast, Carlino and Coulson used the economist's idea of compensating differentials to interpret their findings as an argument for Major League Sports: the NFL presence makes the cities so much more attractive that the inhabitants are ready to pay higher rents (without having higher incomes). Taking the criteria of compensating differentials to the extreme, some of the "negative" findings of e.g. Coates and Humphreys could be interpreted as positive. And, even more embarrassingly, the mentioned "positive" effects on income etc. could also be interpreted as negative.

3 In addition to econometric analysis with "realised data", studies have also been undertaken on the perceived benefits. Studies that examine the effects on an ex-post basis after the conclusion of the World Cup are rarer. Kim and Patrick (2005) analyse Seoul residents' perceptions on impacts of the 2002 World Cup. Using a factor analysis, they found that residents positively perceived the impacts on the factors "tourism resource development and urban revitalisation", "image enhancement and consolidation”, “economic benefits", and interest in foreign countries or their cultures”. They also found a negative perception on "disorder and conflict", "traffic problem and congestion", and "negative economic perception", whereby the authors attribute the latter to the concerns about public costs for the investment or future utilization of the ten new soccer stadia after the World Cup. They found that females, especially housewives, generally had a more positive perception. They also found that the perception may vary over time. Three months after the event, "World Cup fever became diluted” (p. 37). Kim, Gursoy and Lee (2006) also arrive at unsatisfactory perceived economic results, but by contrast to satisfactory cultural results. Stadium costs, which were perceived as high, are explained via social exchange theory in connection with the economic benefits, perceived as unsatisfactory. 
fashion, but which instead examines several alternative periods. In addition it also tests for method sensitivity by running the dataset for the economic effects of major sporting events in parallel with the three methods usually applied in the studies of Baade and Matheson, Coates and Humphreys and Hotchkiss et al. (2003) as well as with a fourth method which attempts to overcome some potential shortcomings associated with the three studies.. Section 2 elaborates on the data, section 3 presents methods and results. Section 4 concludes.

\section{Data}

We examine the employment effects of the 1974 Football World Cup on the 9 host cities (Berlin, Dortmund, Düsseldorf, Frankfurt am Main, Gelsenkirchen, Hamburg, Hannover, Munich and Stuttgart). The analytical framework for the study comprises the data of the 75 most densely populated municipalities in Germany in the year 1974, which also includes all the host cities. The maximum period of observation stretches from 1961 to 1988 . By beginning the observation period in 1961 we use the longest pre-event period of time available. No adequate disaggregated data is available for the time before this date. Due to German reunification, the maximum period of observation ends in 1988 in order to avoid structural breaks and distortions resulting from the reunification process (Buettner and Rincke, 2004).

Data on the number of people employed at NUTS3 level for the years 1961 and 1970 was published in the workplace census of the Statistisches Bundesamt (Federal Statistical Office various years). For the period 1976 to 1988 the data was taken from Bade (1997). The employment figures for the missing years were calculated by interpolating the regional share of employment and multiplying these by the corresponding national numbers, as Bade (1991) does, for example.

Up to 1970 the population figures for the municipalities are taken from the publications of the Arbeitskreis Volkswirtschaftliche Gesamtrechnung der Länder (Macroeconomic Accounting Working Group of the Federal States various years a). From 1977 to 1988 the population figures are taken from the EUROSTAT database. For the years in be- 
tween the population figures were interpolated in proportion to the development of the population in Germany as a whole.

The relative incomes of the municipalities with regard to the corresponding national value were also taken from Arbeitskreis Volkswirtschaftliche Gesamtrechnung der Länder (various years a and b), which published the gross domestic product once in 1961 and every two years from 1964 onwards. From 1976 it also published the gross value added of the municipalities and rural districts. Given that in the year 1976 both the gross domestic product and the gross value added of the municipalities and rural districts were published, it was possible to ensure that these two values did not differ significantly from each other.

The share of gross value added of the economic sectors agriculture and manufacturing, as well as the sectors trade and transport in the municipalities, are taken from Arbeitskreis Volkswirtschaftliche Gesamtrechnung der Länder (various years a and b), where they were published once only in the year 1961 and every two years from the year 1964. The shares of the economic sectors agriculture and manufacturing were aggregated because the data for the individual sectors were not published continually.

\section{Methods and Results}

As an initial look at the possible employment effects of the 1974 World Cup, Illustration 1 contrasts the progression of average employment in the host cities with employment in the other cities over the observation period. 


\section{Illustration 1: Comparison of employment development in the host cities and non- host cities}

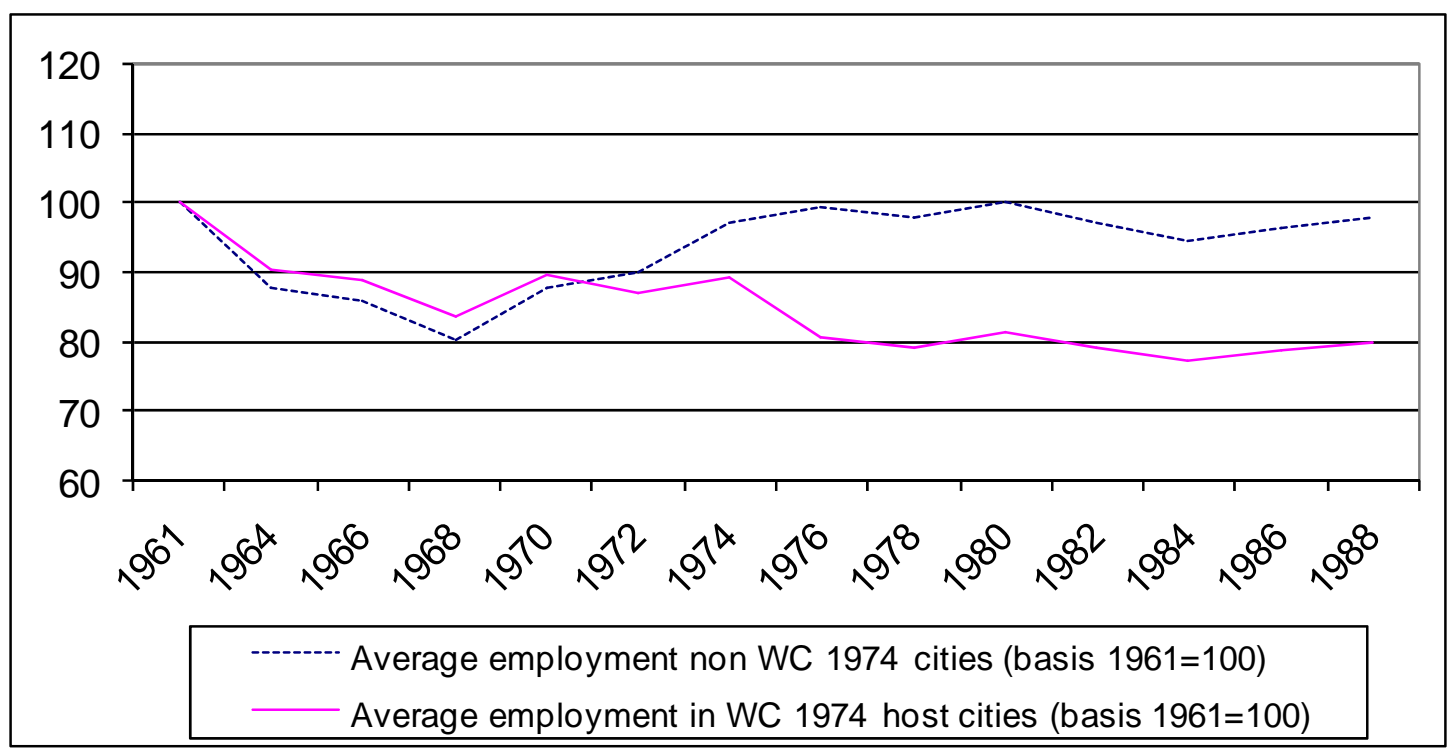

Source: Statistisches Bundesamt (various years), Bade (1997), authors’ own illustration.

Illustration 1 shows that the development of employment in the two groups progressed largely equally at the beginning. From 1970 however, employment in the host cities dropped below that of the host cities. From 1976 onwards the employment in the two groups runs largely parallel again. The question as to whether - whilst controlling for other exogenous influences - the differences in employment development in the two groups are significantly related to the hosting of the 1974 World Cup will be examined below.

In a first step employment in the municipalities is modelled in accordance with the above-mentioned studies by Baade and Matheson in order to estimate the short-term employment effects:

$$
\begin{aligned}
& \partial E_{i, t}=\beta_{0}+\beta_{1} \sum_{i=1}^{n} \partial E_{i, t} / n_{t}+\beta_{2} \partial E_{i, t-1}+\beta_{3} \partial E_{i, t-2}+\beta_{4} \partial E_{i, t-3}+\beta_{5} \ln \text { Pop }_{i, t}+\beta_{6} Y_{i, t}+\beta_{7} O i l_{t} \\
(1)+ & \beta_{8} N R W_{i}+\beta_{9} B A Y_{i}+\beta_{10} N D S_{i}+\beta_{11} H E_{i}+\beta_{12} S H_{i}+\beta_{13} B W_{i}+\beta_{14} H H_{i}+\beta_{15} B R_{i}+\beta_{16} B E_{i} \\
& +\beta_{17} R P_{i}+\beta_{18} T+\beta_{19} W M_{i, t}+\varepsilon
\end{aligned}
$$

with: 


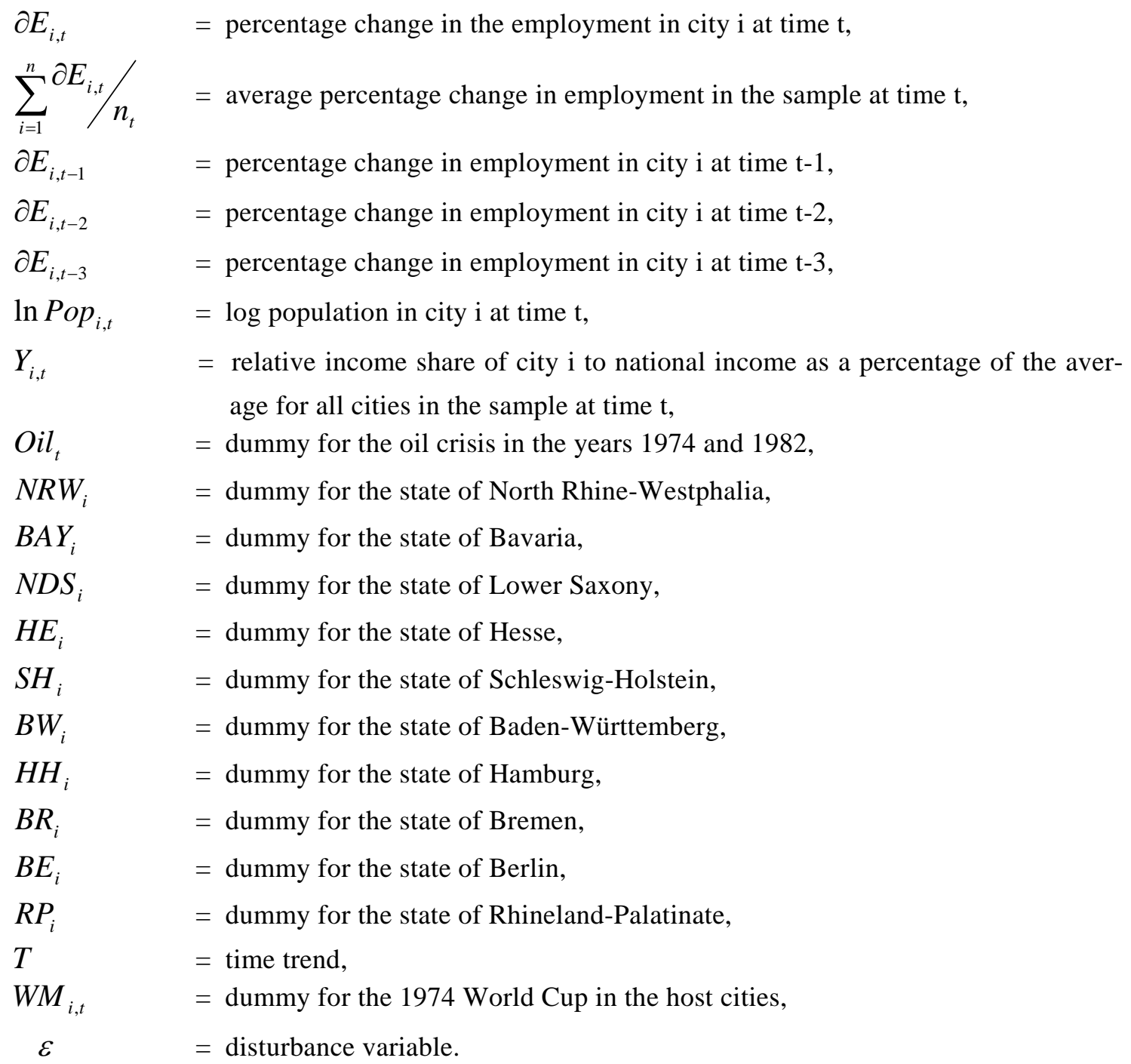

Table 1 shows the results of the estimate in column (1). The dummy variables for the individual states are not significant in any of the cases. They were nevertheless left in the model, in accordance with Baade and Matheson. ${ }^{4}$ The variable $W M_{i, t}$, which measures the employment effects of the 1974 World Cup in the host cities, is shown to be not significantly different from zero.

In accordance with Coates and Humphreys, the effects of the 1974 World Cup are estimated in a second step in a "fixed effects" model.

(2) $\ln E_{i, t}=\beta x_{i, t}+\gamma W M_{i, t}+\mu_{i, t} \quad$ whereby, $\mu_{i, t}=e_{i, t}+v_{i}$

4 The state of Saarland functions as an omitted reference state for the dummy variables for the individual states. 
with:

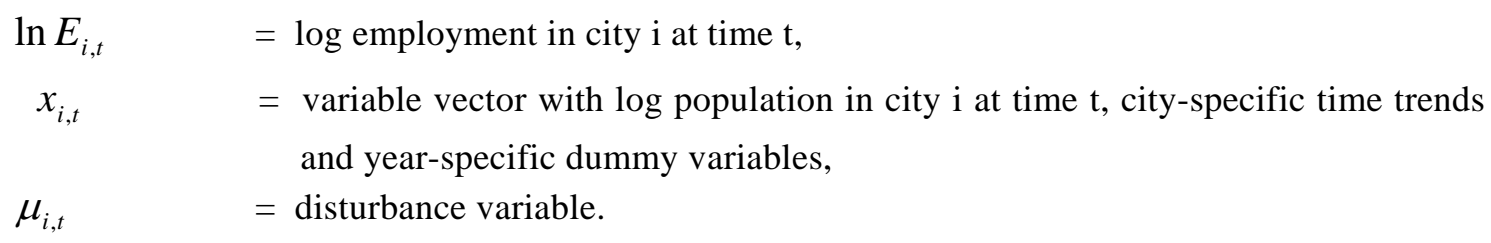

The difference between this model and that of Baade and Matheson is that the latter uses the average change in employment in the entire sample and the deviation of independent variables from the average in the sample in order to take into account general trends that affected all the cities equally. The model by Coates and Humphreys by contrast represents a "fixed effects" model which uses year dummy variables to register effects acting equally on all cities and city-specific time trends to register specific developments in individual cities.

Column (2) of Table 1 does not report the estimated values of the city-specific time trends and the year-specific dummy variables, although they prove to be significant in most cases. ${ }^{5}$ In this estimation model too, the variable $W M_{i, t}$ is also seen to be not significantly different from zero.

In a third step the approach taken by Hotchkiss et al. (2003) for the 1996 Olympic Summer Games in Atlanta is used, which applies a standard "difference in difference" approach to register changes a) in the "intercept", i.e. the employment and wage levels and b) in the "slope", i.e. the growth of the two variables. The difference in difference approach compares the variables of interest before and after the occurrence of a specific event $^{6}$ in a region in which the variables changed with another region unaffected by the event. The approach assumes that the development in the unaffected region would correspond to that in the affected region if the event had not happened. In contrast to the difference in difference approach, both Baade and Matheson and Coates and Humphreys simultaneously compare the development in the year of the World Cup in the

5 Complete estimation results can be provided by the authors on request.

6 This often relates to political events, such as the introduction of new laws. The classical application of the difference in difference approach originates from Card and Krueger (1994) who used it to examine the effects of minimum wages in two US-American states. 
host cities with the development in non-host cities as well as with the development in host cities in all the non-World Cup years (both before and after the World Cup). The essential difference between the approach developed by Hotchkiss et al. (2003) and the work of Baade and Matheson and Coates and Humphreys is that the latter test exclusively for short-term effects in the year of the tournament itself, where as the approach by Hotchkiss et al. (2003) also tests for long-term effects.

For the 1974 Football World Cup in Germany, the model by Hotchkiss et al. (2003) has the following form for employment effects in the levels:

(3) $\ln E_{i, t}=\beta_{0}+\beta_{1} L P_{i, t}+\beta_{2} H V_{i, t}+\beta_{3} \ln P_{o p 1965}+\beta_{4} W M_{i}+\beta_{5} P O S T_{t}+\beta_{6} W M_{i} * P O S T_{t}+\varepsilon$

with:

$L P_{i, t} \quad=$ share of gross value added of agriculture and manufacturing in city $\mathrm{i}$ at time $\mathrm{t}$,

$H V_{i, t} \quad=$ share of of gross value added of trade and transport in city i at time $\mathrm{t}$,

$\ln$ Pop $1965_{i}=\log$ population in city i in the year 1965,

$\operatorname{POST}_{t} \quad=$ dummy for the period after the World Cup (post-event period),

$\varepsilon \quad=$ disturbance variable.

The variables $L P_{i, t}, H V_{i, t}$ and $\ln P o p 1965_{i}$ are used to take into account observable differences between cities in the sample. $P O S T_{t}$ is a dummy variable for the period following the hosting of the World Cup. Analogously to the method used by Hotchkiss et al. (2003), the model is estimated with various assumptions about the post-event period beginning in the years between 1970 and 1978. The best result (largest F statistic) was achieved for a post-event period beginning in 1974. Column (3) in Table 1 represents the corresponding estimate results. The relevant variable $W M_{i} * P O S T_{t}$ is not significant. This indicates that the employment levels in the 9 host cities did not develop significantly differently from those in the other cities within the observation period.

To test for an effect of the 1974 World Cup on employment growth equation (4) is estimated in accordance with Hotchkiss et al. (2003) :

$\ln E_{i, t}=\alpha_{0}+\alpha_{1} L P_{i, t}+\alpha_{2} H V_{i, t}+\alpha_{3} \ln P_{o p 1965}+\alpha_{4} T+\alpha_{5} T * W M_{i}+\alpha_{6} T * P O S T_{t}$ $+\alpha_{7} T * W M_{i} * \mathrm{POST}_{t}+\varepsilon$ 
Once again the model was tested for different years in which the post-event period began. With this model the best fit (largest F statistic) was for the starting year 1972. However, for the purpose of comparability of the results with the other models Table 1 once again only shows the results for the post-event period from 1974. Column (4) in Table 1 shows that the relevant variable $t * W M_{i} * P O S T_{t}$ is significantly negative - the World Cup host cities demonstrate a significantly negative employment trend in comparison with the other, non-host cities. ${ }^{7}$

However, Bertrand et al. (2004) point out that difference in difference models tend to overestimate the significance of the results. In another research context, ${ }^{8}$ Galster et al. (2004) also argue that a standard difference in difference approach can supply distorted results. For example, a city employment level which is different to the period before the World Cup can be due to the continuation of a previously existing positive trend. Accordingly in the following the estimations detailed above are extended to account for changes in both the levels and the trends. Moreover, this extended model also includes dummy variables for the various states in the Federal Republic of Germany as additional spatial control variables, so that different developments in the country's various regions can be taken into account. ${ }^{9}$

To account for potential effects that already occurred in the preparatory phase before the actual hosting of the World Cup in the year 1974 due to investments in stadia and infrastructure we estimate the model for the start of the post-event period between 1970 and 1978. This means that potentially delayed effects that only arose some time after the World Cup can also be registered.

By examining all the alternative assumptions on the duration of the post-event period between at least 2 and a maximum of 18 years (for the longest post-event period 1970-

7 For the post-event period from 1972 the variable $t^{*} W M_{i} * P O S T_{t}$ also proves to be significantly negative (Coefficient: -0.027264**, Std. Error: 0.007142).

8 They examined the effect of residential homes for disabled people on property prices in the neighbourhood.

9 Here too, the Saarland serves as an omitted reference state for the dummy variables. 
1988), our model, in contrast to previous models, is able to simultaneously register both the short-term and long-term employment effects of the 1974 World Cup.

Together with the extensions described above our model has the following form:

$$
\begin{aligned}
& \ln E_{i, t}=\beta_{0}+\beta_{1} W M_{i}+\beta_{2} \text { Post }_{t}+\beta_{3} \text { PostWM }_{i, t}+\beta_{4} \operatorname{TrWM}_{i}+\beta_{5} \operatorname{TrPost}_{t}+\beta_{6} \operatorname{TrPostWM}_{i, t}+\beta_{7} T \\
& (5)+\beta_{8} L P_{i, t}+\beta_{9} H V_{i, t}+\beta_{10} \ln \operatorname{Pop}_{i, t}+\beta_{11} Y_{i, t}+\beta_{12} N R W_{i}+\beta_{13} \text { BAY }_{i}+\beta_{14} N D S_{i}+\beta_{15} H E_{i}+\beta_{16} \text { SH }_{i}+\beta_{17} B W_{i} \\
& \quad+\beta_{18} H H_{i}+\beta_{19} B R_{i}+\beta_{20} B E_{i}+\beta_{21} R P_{i}+\varepsilon .
\end{aligned}
$$

With:

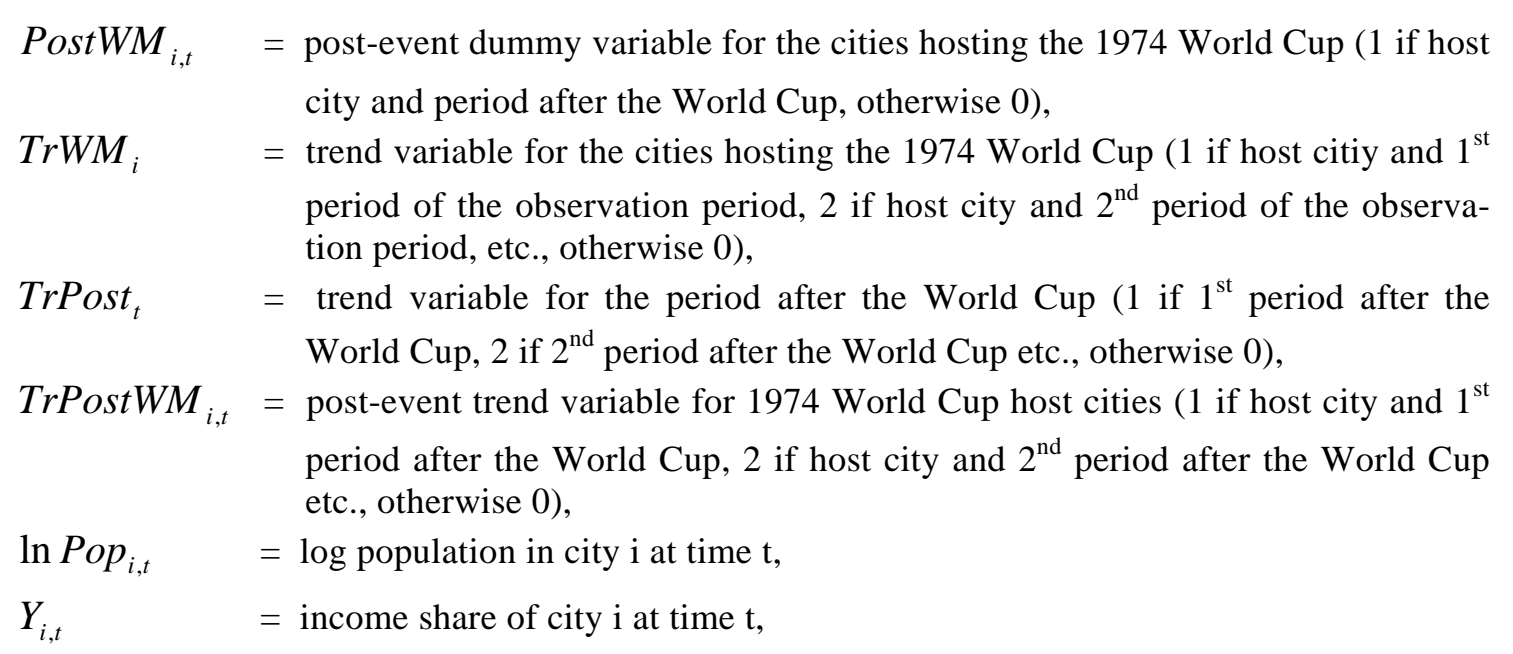

Column (5) of Table 1 lists the results in an exemplary way for the post-event period 1974-1988. Most variables prove to be significant at the $5 \%$ or $1 \%$ level and have the expected signs. The coefficient of $W M_{i}$ is significantly negative, indicating that the World Cup host cities display a lower level of employment across the period 1961 until 1988 in comparison with the non-host cities. By contrast, the variable PostWM $M_{i, t}$ which is relevant for the World Cup related effects in the employment levels is not significant. The variable for World Cup related effects in the employment trends $\operatorname{TrPostWM_{i,t}}$ is also not significant.

For the other post-event periods examined, the results of the variables relevant for World Cup related employment effects, $\operatorname{PostWM}_{i, t}$ and $\operatorname{TrPostWM}_{i, t}$, are listed in Tables 2-6. The two variables prove to be significantly different from zero in none of the post-event periods we examined. Thus the hypothesis that neither short-term nor long- 
term employment effects resulted from the hosting of the 1974 Football World Cup cannot be rejected.

Table 1: Estimates of equations (1) to (5), post-event period 1974 - 1988

\begin{tabular}{|c|c|c|c|c|c|}
\hline Equation & (1) & (2) & (3) & (4) & (5) \\
\hline Dependent Variable & $\partial E_{i, t}$ & $\ln E_{i, t}$ & $\ln E_{i, t}$ & $\ln E_{i, t}$ & $\ln E_{i, t}$ \\
\hline C & $\begin{array}{l}-2.683946 \\
(3.919387)\end{array}$ & $\begin{array}{l}-0.919290 * * \\
(0.127336)\end{array}$ & $\begin{array}{l}0.085829 \\
(0.193566)\end{array}$ & $\begin{array}{l}0.072946 \\
(0.191430)\end{array}$ & $\begin{array}{l}-0.554523 * \\
(0.226352)\end{array}$ \\
\hline$\sum_{i=1}^{n} \partial E_{i, t} / n_{t}$ & $\begin{array}{l}0.982464 * * \\
(0.032637)\end{array}$ & & & & \\
\hline$\partial E_{i, t-1}$ & $\begin{array}{l}0.106701^{* *} \\
(0.017933)\end{array}$ & & & & \\
\hline$\partial E_{i, t-2}$ & $\begin{array}{l}0.109341^{* * *} \\
(0.023900)\end{array}$ & & & & \\
\hline$\partial E_{i, t-3}$ & $\begin{array}{l}0.031218 \\
(0.019455)\end{array}$ & & & & \\
\hline $\begin{array}{l}\ln P o p_{i, t} \\
\text { or } \ln P o p 1965_{i}\end{array}$ & $\begin{array}{l}0.165848 \\
(0.312611)\end{array}$ & $\begin{array}{l}1.023616^{* *} \\
(0.010462)\end{array}$ & $\begin{array}{l}0.925694 * * \\
(0.015441)\end{array}$ & $\begin{array}{l}0.942906 * * \\
(0.014599)\end{array}$ & $\begin{array}{l}0.952801 * * \\
(0.017631)\end{array}$ \\
\hline$L P_{i, t}$ & & & $\begin{array}{l}0.000404 \\
(0.000900)\end{array}$ & $\begin{array}{l}-0.000382 \\
(0.000941)\end{array}$ & $\begin{array}{l}0.004725^{* *} \\
(0.000626)\end{array}$ \\
\hline$H V_{i, t}$ & & & $\begin{array}{l}-0.001550 \\
(0.002186)\end{array}$ & $\begin{array}{l}-0.004000 \\
(0.002242)\end{array}$ & $\begin{array}{l}0.005243 * * \\
(0.001570)\end{array}$ \\
\hline$Y_{i, t}$ & $\begin{array}{l}-0.002178 \\
(0.002217)\end{array}$ & & & & $\begin{array}{l}16.14821^{* *} \\
(2.050756)\end{array}$ \\
\hline $\mathrm{Oil}_{t}$ & $\begin{array}{c}-0.581866^{*} \\
(0.276831)\end{array}$ & & & & \\
\hline$N R W_{i}$ & $\begin{array}{l}0.939786 \\
(1.038396)\end{array}$ & & & & $\begin{array}{l}-0.168654^{* *} \\
(0.057786)\end{array}$ \\
\hline$B A Y_{i}$ & $\begin{array}{l}1.649544 \\
(1.085243)\end{array}$ & & & & $\begin{array}{l}0.129417^{*} \\
(0.060153)\end{array}$ \\
\hline$N D S_{i}$ & $\begin{array}{l}1.168423 \\
(1.079738)\end{array}$ & & & & $\begin{array}{l}0.049360 \\
(0.060225)\end{array}$ \\
\hline$H E_{i}$ & $\begin{array}{l}1.016793 \\
(1.102596)\end{array}$ & & & & $\begin{array}{l}0.174150^{* * *} \\
(0.061385)\end{array}$ \\
\hline $\mathrm{SH}_{i}$ & $\begin{array}{l}0.606405 \\
(1.113731)\end{array}$ & & & & $\begin{array}{l}-0.072287 \\
(0.062114)\end{array}$ \\
\hline$B W_{i}$ & $\begin{array}{l}1.301372 \\
(1.078571)\end{array}$ & & & & $\begin{array}{l}0.212988 * * \\
(0.059935)\end{array}$ \\
\hline$H H_{i}$ & $\begin{array}{l}1.282819 \\
(1.565882)\end{array}$ & & & & $\begin{array}{l}-0.524655^{* *} \\
(0.091281)\end{array}$ \\
\hline$B R_{i}$ & $\begin{array}{l}0.599471 \\
(1.175127)\end{array}$ & & & & $\begin{array}{l}-0.122954 \\
(0.066457)\end{array}$ \\
\hline$B E_{i}$ & $\begin{array}{l}0.206476 \\
(1.415940)\end{array}$ & & & & $\begin{array}{l}-0.443290 * * \\
(0.079612)\end{array}$ \\
\hline$R P_{i}$ & $\begin{array}{l}1.554397 \\
(1.103832)\end{array}$ & & & & $\begin{array}{l}0.075215 \\
(0.061260)\end{array}$ \\
\hline$T_{t}$ & $\begin{array}{l}-0.008571 \\
(0.016654)\end{array}$ & & & $\begin{array}{l}-0.013560 * * \\
(0.003392)\end{array}$ & $\begin{array}{l}-0.017104 * * \\
(0.002439)\end{array}$ \\
\hline
\end{tabular}




\begin{tabular}{|c|c|c|c|c|c|}
\hline$W M_{i}$ & & & $\begin{array}{l}0.222968 * * \\
(0.047549)\end{array}$ & & $\begin{array}{c}-0.118500^{*} \\
(0.056526)\end{array}$ \\
\hline $\mathrm{POST}_{t}$ & & & $\begin{array}{l}0.091251 * * \\
(0.024312)\end{array}$ & & $\begin{array}{l}0.115107 * * \\
(0.023177)\end{array}$ \\
\hline $\begin{array}{l}W M_{i} * \mathrm{POST}_{t} \text { or } \\
\text { PostWM }_{i, t}\end{array}$ & & & $\begin{array}{l}-0.198408 * * \\
(0.052804)\end{array}$ & & $\begin{array}{l}-0.045967 \\
(0.064632)\end{array}$ \\
\hline $\begin{array}{l}T^{*} W M_{i} \\
\text { or } \operatorname{Tr} W M_{i}\end{array}$ & & & & $\begin{array}{l}0.021121^{* *} \\
(0.005848)\end{array}$ & $\begin{array}{l}0.013185^{*} \\
(0.006715)\end{array}$ \\
\hline $\begin{array}{l}T * \mathrm{POST}_{t} \\
\text { or } \text { TrPost }_{t}\end{array}$ & & & & $\begin{array}{l}0.012301^{* *} \\
(0.002545)\end{array}$ & $\begin{array}{l}0.021396 * * \\
(0.002922)\end{array}$ \\
\hline $\begin{array}{l}T * W M_{i} * \mathrm{POST}_{t} \\
\text { or TrPostWM } \\
i, t\end{array}$ & & & & $\begin{array}{l}-0.021648 * * \\
(0.005646)\end{array}$ & $\begin{array}{l}-0.015136 \\
(0.008184)\end{array}$ \\
\hline$W M_{i, t}$ & $\begin{array}{l}-1.537287 \\
(0.964414)\end{array}$ & $\begin{array}{l}0.050199 \\
(0.048046)\end{array}$ & & & \\
\hline Adj. $R^{2}$ & 0.645874 & 0.975136 & 0.891956 & 0.891894 & 0.958337 \\
\hline
\end{tabular}

*or, respectively $* *=$ significant at the $5 \%$ or $1 \%$ level 
Table 2: Results of employment effects from the 1974 World Cup, post-event period from 1970

\begin{tabular}{|c|c|c|c|}
\hline Period to & Adj. $\mathrm{R}^{2}$ & Variable & $\begin{array}{l}\text { Coefficient } \\
\text { (Std. Error) }\end{array}$ \\
\hline \multirow[t]{2}{*}{1972} & 0.958308 & PostWM $_{i, t}$ & $\begin{array}{l}-0.037439 \\
(0.117977)\end{array}$ \\
\hline & & $\operatorname{TrPost} W M_{i, t}$ & $\begin{array}{l}0.028583 \\
(0.046747)\end{array}$ \\
\hline \multirow[t]{2}{*}{1974} & 0.957073 & PostWM $_{i, t}$ & $\begin{array}{l}0.010220 \\
(0.099297)\end{array}$ \\
\hline & & TrPostWM $M_{i, t}$ & $\begin{array}{l}-0.000198 \\
(0.025923)\end{array}$ \\
\hline \multirow[t]{2}{*}{1976} & 0.958451 & PostWM $_{i, t}$ & $\begin{array}{l}0.044195 \\
(0.088056)\end{array}$ \\
\hline & & TrPostWM $M_{i, t}$ & $\begin{array}{l}-0.015167 \\
(0.018558)\end{array}$ \\
\hline \multirow[t]{2}{*}{1978} & 0.958974 & PostWM $_{i, t}$ & $\begin{array}{l}0.050022 \\
(0.081676)\end{array}$ \\
\hline & & $\operatorname{TrPostWM}_{i, t}$ & $\begin{array}{l}-0.017222 \\
(0.015446)\end{array}$ \\
\hline \multirow[t]{2}{*}{1980} & 0.959253 & PostWM $_{i, t}$ & $\begin{array}{l}0.041197 \\
(0.077417)\end{array}$ \\
\hline & & $\operatorname{TrPost} W M_{i, t}$ & $\begin{array}{l}-0.014936 \\
(0.013901)\end{array}$ \\
\hline \multirow[t]{2}{*}{1982} & 0.959383 & PostWM $_{i, t}$ & $\begin{array}{l}0.035864 \\
(0.074344)\end{array}$ \\
\hline & & TrPostWM ${ }_{i, t}$ & $\begin{array}{l}-0.013668 \\
(0.013048)\end{array}$ \\
\hline \multirow[t]{2}{*}{1984} & 0.959417 & PostWM $_{i, t}$ & $\begin{array}{l}0.032779 \\
(0.072017)\end{array}$ \\
\hline & & $\operatorname{TrPostWM_{i,t}}$ & $\begin{array}{l}-0.013013 \\
(0.012537)\end{array}$ \\
\hline \multirow[t]{2}{*}{1986} & 0.959436 & $\operatorname{PostWM}_{i, t}$ & $\begin{array}{l}0.033656 \\
(0.070178)\end{array}$ \\
\hline & & TrPostWM $M_{i, t}$ & $\begin{array}{l}-0.013190 \\
(0.012207)\end{array}$ \\
\hline \multirow[t]{2}{*}{1988} & 0.959277 & PostWM $_{i, t}$ & $\begin{array}{l}0.035661 \\
(0.068813)\end{array}$ \\
\hline & & $\operatorname{TrPost} W M_{i, t}$ & $\begin{array}{l}-0.013528 \\
(0.012003)\end{array}$ \\
\hline
\end{tabular}

$*$ or, respectively $* *=$ significant at the $5 \%$ or $1 \%$ level 
Table 3: Results of employment effects from the 1974 World Cup, post-event period from 1972

\begin{tabular}{|c|c|c|c|}
\hline Period to & Adj. $\mathrm{R}^{2}$ & Variable & $\begin{array}{l}\text { Coefficient } \\
\text { (Std. Error) }\end{array}$ \\
\hline \multirow[t]{2}{*}{1974} & \multirow[t]{2}{*}{0.955852} & PostWM $_{i, t}$ & $\begin{array}{l}0.080795 \\
(0.117635)\end{array}$ \\
\hline & & TrPostWM $M_{i, t}$ & $\begin{array}{l}-0.026977 \\
(0.047020)\end{array}$ \\
\hline \multirow[t]{2}{*}{1976} & \multirow[t]{2}{*}{0.957079} & PostWM $_{i, t}$ & $\begin{array}{l}0.089852 \\
(0.094718)\end{array}$ \\
\hline & & TrPostWM $M_{i, t}$ & $\begin{array}{l}-0.033487 \\
(0.024350)\end{array}$ \\
\hline \multirow[t]{2}{*}{1978} & \multirow[t]{2}{*}{0.957631} & PostWM $_{i, t}$ & $\begin{array}{l}0.074238 \\
(0.084277)\end{array}$ \\
\hline & & TrPostWM $M_{i, t}$ & $\begin{array}{l}-0.026859 \\
(0.016695)\end{array}$ \\
\hline \multirow[t]{2}{*}{1980} & \multirow[t]{2}{*}{0.958009} & PostWM $_{i, t}$ & $\begin{array}{l}0.051945 \\
(0.077959)\end{array}$ \\
\hline & & $\operatorname{TrPost} W M_{i, t}$ & $\begin{array}{l}-0.019418 \\
(0.013251)\end{array}$ \\
\hline \multirow[t]{2}{*}{1982} & \multirow[t]{2}{*}{0.958198} & PostWM $_{i, t}$ & $\begin{array}{l}0.039718 \\
(0.073676)\end{array}$ \\
\hline & & $\operatorname{TrPost} M_{i, t}$ & $\begin{array}{l}-0.015959 \\
(0.011479)\end{array}$ \\
\hline \multirow[t]{2}{*}{1984} & \multirow[t]{2}{*}{0.958286} & PostWM $_{i, t}$ & $\begin{array}{l}0.032536 \\
(0.070549)\end{array}$ \\
\hline & & TrPostWM $M_{i, t}$ & $\begin{array}{l}-0.014224 \\
(0.010479)\end{array}$ \\
\hline \multirow[t]{2}{*}{1986} & \multirow[t]{2}{*}{0.958378} & $\operatorname{PostWM}_{i, t}$ & $\begin{array}{l}0.030851 \\
(0.068121)\end{array}$ \\
\hline & & TrPostWM $M_{i, t}$ & $\begin{array}{l}-0.013903 \\
(0.009869)\end{array}$ \\
\hline \multirow[t]{2}{*}{1988} & \multirow[t]{2}{*}{0.958291} & PostWM $_{i, t}$ & $\begin{array}{l}0.030943 \\
(0.066308)\end{array}$ \\
\hline & & TrPostWM $M_{i, t}$ & $\begin{array}{l}-0.013944 \\
(0.009493)\end{array}$ \\
\hline
\end{tabular}

$*$ or, respectively $* *=$ significant at the $5 \%$ or $1 \%$ level 
Table 4: Results of employment effects from the 1974 World Cup, post-event period from 1974

\begin{tabular}{|c|c|c|c|}
\hline Period to & Adj. $\mathrm{R}^{2}$ & Variable & $\begin{array}{l}\text { Coefficient } \\
\text { (Std. Error) }\end{array}$ \\
\hline \multirow[t]{2}{*}{1976} & \multirow[t]{2}{*}{0.957058} & PostWM $_{i, t}$ & $\begin{array}{l}0.007645 \\
(0.112761)\end{array}$ \\
\hline & & TrPostWM ${ }_{i, t}$ & $\begin{array}{l}-0.041720 \\
(0.045727)\end{array}$ \\
\hline \multirow[t]{2}{*}{1978} & \multirow[t]{2}{*}{0.957729} & PostWM $_{i, t}$ & $\begin{array}{l}-0.016915 \\
(0.090715)\end{array}$ \\
\hline & & $\operatorname{TrPostWM_{i,t}}$ & $\begin{array}{l}-0.027305 \\
(0.023289)\end{array}$ \\
\hline \multirow[t]{2}{*}{1980} & \multirow[t]{2}{*}{0.957981} & PostWM $_{i, t}$ & $\begin{array}{l}-0.040220 \\
(0.080626)\end{array}$ \\
\hline & & $\operatorname{TrPost} W M_{i, t}$ & $\begin{array}{l}-0.017560 \\
(0.015539)\end{array}$ \\
\hline \multirow[t]{2}{*}{1982} & \multirow[t]{2}{*}{0.958238} & PostWM $_{i, t}$ & $\begin{array}{l}-0.048632 \\
(0.074354)\end{array}$ \\
\hline & & $\operatorname{TrPostWM_{i,t}}$ & $\begin{array}{l}-0.014739 \\
(0.011910)\end{array}$ \\
\hline \multirow[t]{2}{*}{1984} & \multirow[t]{2}{*}{0.958412} & PostWM $_{i, t}$ & $\begin{array}{l}-0.051806 \\
(0.070032)\end{array}$ \\
\hline & & $\operatorname{TrPost} W M_{i, t}$ & $\begin{array}{l}-0.013874 \\
(0.009972)\end{array}$ \\
\hline \multirow[t]{2}{*}{1986} & \multirow[t]{2}{*}{0.958461} & PostWM $M_{i, t}$ & $\begin{array}{l}-0.049513 \\
(0.066919)\end{array}$ \\
\hline & & $\operatorname{TrPost} W M_{i, t}$ & $\begin{array}{l}-0.014436 \\
(0.008856)\end{array}$ \\
\hline \multirow[t]{2}{*}{1988} & \multirow[t]{2}{*}{0.958337} & PostWM $_{i, t}$ & $\begin{array}{l}-0.045967 \\
(0.064632)\end{array}$ \\
\hline & & TrPostWM $M_{i, t}$ & $\begin{array}{l}-0.015136 \\
(0.008184)\end{array}$ \\
\hline
\end{tabular}

*or, respectively $* *=$ significant at the $5 \%$ or $1 \%$ level 
Table 5: Results of employment effects from the 1974 World Cup, post-event period from 1976

\begin{tabular}{|c|c|c|c|}
\hline Period to & Adj. $\mathrm{R}^{2}$ & Variable & $\begin{array}{l}\text { Coefficient } \\
\text { (Std. Error) }\end{array}$ \\
\hline \multirow[t]{2}{*}{1978} & 0.955812 & PostWM $_{i, t}$ & $\begin{array}{l}-0.086321 \\
(0.112568)\end{array}$ \\
\hline & & $\operatorname{TrPost} W M_{i, t}$ & $\begin{array}{l}-0.011314 \\
(0.045983)\end{array}$ \\
\hline \multirow[t]{2}{*}{1980} & 0.956334 & PostWM $_{i, t}$ & $\begin{array}{l}-0.096280 \\
(0.090127)\end{array}$ \\
\hline & & $\operatorname{TrPostWM_{i,t}}$ & $\begin{array}{l}-0.005000 \\
(0.023234)\end{array}$ \\
\hline \multirow[t]{2}{*}{1982} & 0.956689 & PostWM $_{i, t}$ & $\begin{array}{l}-0.093436 \\
(0.079541)\end{array}$ \\
\hline & & $\operatorname{TrPostWM_{i,t}}$ & $\begin{array}{l}-0.006164 \\
(0.015172)\end{array}$ \\
\hline \multirow[t]{2}{*}{1984} & 0.956930 & PostWM $_{i, t}$ & $\begin{array}{l}-0.089199 \\
(0.073049)\end{array}$ \\
\hline & & TrPostWM $M_{i, t}$ & $\begin{array}{l}-0.007613 \\
(0.011332)\end{array}$ \\
\hline \multirow[t]{2}{*}{1986} & 0.957080 & PostWM $_{i, t}$ & $\begin{array}{l}-0.081023 \\
(0.068611)\end{array}$ \\
\hline & & $\operatorname{TrPostWM_{i,t}}$ & $\begin{array}{l}-0.009845 \\
(0.009237)\end{array}$ \\
\hline \multirow[t]{2}{*}{1988} & 0.957072 & PostWM $_{i, t}$ & $\begin{array}{l}-0.073202 \\
(0.065424)\end{array}$ \\
\hline & & $\operatorname{TrPostWM_{i,t}}$ & $\begin{array}{l}-0.011573 \\
(0.008007)\end{array}$ \\
\hline
\end{tabular}

*or, respectively ** = significant at the $5 \%$ or $1 \%$ level 
Table 6: Results of employment effects from the 1974 World Cup, post-event period from 1978

\begin{tabular}{|c|c|c|c|}
\hline Period to & Adj. $\mathrm{R}^{2}$ & Variable & $\begin{array}{l}\text { Coefficient } \\
\text { (Std. Error) }\end{array}$ \\
\hline \multirow[t]{2}{*}{1980} & 0.955848 & PostWM $M_{i, t}$ & $\begin{array}{l}-0.080934 \\
(0.110582)\end{array}$ \\
\hline & & TrPostWM $M_{i, t}$ & $\begin{array}{l}0.004984 \\
(0.045560)\end{array}$ \\
\hline \multirow[t]{2}{*}{1982} & 0.956198 & PostWM $_{i, t}$ & $\begin{array}{l}-0.071209 \\
(0.088237)\end{array}$ \\
\hline & & TrPostWM $M_{i, t}$ & $\begin{array}{l}-0.001125 \\
(0.022892)\end{array}$ \\
\hline \multirow[t]{2}{*}{1984} & 0.956476 & PostWM $_{i, t}$ & $\begin{array}{l}-0.065185 \\
(0.077679)\end{array}$ \\
\hline & & TrPostWM $M_{i, t}$ & $\begin{array}{l}-0.003965 \\
(0.014781)\end{array}$ \\
\hline \multirow[t]{2}{*}{1986} & 0.956649 & PostWM $_{i, t}$ & $\begin{array}{l}-0.055861 \\
(0.071243)\end{array}$ \\
\hline & & $\operatorname{TrPost} W M_{i, t}$ & $\begin{array}{l}-0.007132 \\
(0.010870)\end{array}$ \\
\hline \multirow[t]{2}{*}{1988} & 0.956672 & PostWM $_{i, t}$ & $\begin{array}{l}-0.048050 \\
(0.066868)\end{array}$ \\
\hline & & TrPostWM $M_{i, t}$ & $\begin{array}{l}-0.009196 \\
(0.008705)\end{array}$ \\
\hline
\end{tabular}

*or, respectively $* *=$ significant at the $5 \%$ or $1 \%$ level

In order to exclude the possibility that our results might be misleading - in as much as although the host cities did not develop in a significantly different way from the nonhost cities, Germany as a whole (within the territory of the Federal Republic of the time) might nevertheless have experienced positive employment effects, perhaps due to a spill-over effects from the World Cup on non-host cities - employment in the Federal Republic of Germany was used as a dependent variable in a regression for the years 1961 to 1988 . The independent variables were the lagged employment, the real gross domestic product, the real wage levels ${ }^{10}$, a dummy for the oil crises in 1974 and 1982, a time trend and a dummy for the World Cup in 1974. Data on employment figures, gross domestic product and wages for the entire observation period from 1960 to 1990 were taken from the data provided by the Statistisches Bundesamt (2007a, 2007b, 2007c). ${ }^{11}$

\footnotetext{
${ }^{10}$ Here we used the average gross monthly wage of workers in manufacturing industry.

11 The gross domestic product and the wages were adjusted for price using the cost of living index for 4person households of blue-collar workers and medium-earning white-collar workers (basis 1995=100) (Statistisches Bundesamt (2007d).
} 
The variable for employment effects of the World Cup, $W M 74_{t}$ proved to be not significantly different from zero. ${ }^{12}$

\section{Conclusions and economic policy implications}

Our estimates on the basis of four different estimation approaches come to the conclusion that the 1974 Football World Cup held in Germany was not able, neither in the short nor in the long term, to generate employment effects in the host cities that were significantly positively different from zero. The study and its results are unique to the extent that - with the exception of Hagn and Maennig (2007) - for the first time, employment effects of a Football World Cup or a major sporting event outside of the USA have been examined in a multivariate study. Nevertheless the results are in line with the evidence from studies of sport events. Our results not only correspond with those of Baade and Matheson (2004), which were unable to prove any income effects significantly different from zero in the host cities of the 1994 Football World Cup in the USA; they also correspond with almost all ex post multivariate income and employment analyses of major sporting events and venues which, with the exception of Hotchkiss et al. (2003) for the 1996 Olympic Summer Games in Atlanta, show no income and/or employment effects that are significantly positively different from zero.

We nevertheless hesitate to share the concern expressed both implicitly and explicitly in many of the comparable sports economy studies that the positive effects of the sporting events claimed by many sports protagonists are not true and that (bids to host) major sporting events are inefficient from an economic point of view, for three reasons. Firstly, other effects such as the feelgood benefit for the population and/or difficult to quantify image effects may be sufficiently important to justify major sporting events and/or subsidies for them via public funds. In both of the above-mentioned fields of possible effects, sporting economic empiricism is still in its infancy. ${ }^{13}$

\footnotetext{
12 Details of the estimate are available from the authors on request.

${ }^{13}$ For the measurement of the experiential benefit of the Olympic Games in London 2012 cf. Atkinson et al. (2006), and Heyne et al. (2007) for the Football World Cup.
} 
Secondly, the treatment group in the selected form of municipality areas might be too large and too highly aggregated to statistically prove significant effects. Studies on the effects of major sports venues on property values in surrounding areas indicate a maximum affect area of around 3,000 metres (Tu, 2005; Ahlfeldt and Maennig, 2007a, b).

Thirdly, the employment effects claimed by the sports protagonists, which are usually based on corresponding ex-ante impact studies, cannot strictly speaking be rejected by testing for significant differences from zero. Their rejection would be possible if the postulated values were tested directly. However, this would not be regularly successful in the relevant studies because the effects claimed are so close to zero. To illustrate this: the value of -0.045 for PostWM $M_{i, t}$ in Table 1, with a standard deviation of 0.0646 is usually interpreted to mean that there are no positive employment results. Sports protagonists can argue that with the existing estimates positive employment effects of up to around $(-0.045+2 * 0.0646=) 0.0842$ cannot be refuted. This would nevertheless correspond, ceteris paribus, to an employment impulse of an increase of 40,923 jobs in the average employment levels in the host cities in the period between 1974 and 1988. 


\section{Literature}

Ahlert, G., 2000. The Economic Effects of the Soccer World Cup 2006 in Germany with Regard to Different Financing. Economic System Research, 13(1), 109-127.

Ahlfeldt, G., Maennig, W., 2007a. Award-Winning Architecture and Urban Revitalization: The Case of "Olympic Arenas". Berlin Prenzlauer Berg. Hamburg Working Paper Series in Economic Policy Nr. 1/ 2007.

Ahlfeldt, G., Maennig, W., 2007b. Impact of Sports Arenas on Land Values: Evidence from Berlin. Hamburg Working Paper Series in Economic Policy Nr. 3/ 2007.

Arbeitskreis Volkswirtschaftliche Gesamtrechnung der Länder, 1976. Bruttoinlandsprodukt und Bruttowertschöpfung der kreisfreien Städte und Landkreise in der Bundesrepublik Deutschland (Gross domestic product and gross value added of the municipalities and rural districts in the Federal Republic of Germany), Stuttgart.

Arbeitskreis Volkswirtschaftliche Gesamtrechnungen der Länder, various years, a. Bruttoinlandsprodukt der kreisfreien Städte und Landkreise in der Bundesrepublik Deutschland (Gross domestic product of the municipalities and rural districts in the Federal Republic of Germany), Stuttgart.

Arbeitskreis Volkswirtschaftliche Gesamtrechnungen der Länder, various years, b. Bruttowertschöpfung der kreisfreien Städte und Landkreise in der Bundesrepublik Deutschland (Gross value added of the municipalities and rural districts in the Federal Republic of Germany), Stuttgart.

Atkinson, G., Mourato, S., Szymanski, S., 2006. Quantifying the "un-quantifiable”: Valuing the intangible Impacts of Hosting the Summer Olympic Games. London, unpublished manuscript London School of Economics and Imperial College London.

Baade R.A., 1987. Is There an Economic Rationale for Subsidizing Sports Stadiums? Heartland Policy Study No.13.

Baade, R.A., 1994. Stadiums, Professional Sports, and Economic Development: Assessing the Reality. The Heartland Institute Policy Study, 62.

Baade, R.A., 1996. Professional Sports as Catalysts for Metropolitan Economic Development. Journal of Urban Affairs 18(1), 1-17.

Baade, R.A., Dye, R., 1990. The Impact of Stadiums and Professional Sports on Metropolitan Area Development. Development Growth and Change, Spring 21 (2), 1-14.

Baade, R.A., Matheson, V.A., 2000. An Assessment of the Economic Impact of the American Football Championship, the Super Bowl, on Host Communities. Reflets et Perspectives 39, Number 2-3, 35-46.

Baade, R.A., Matheson, V.A., 2001. Home Run or Wild Pitch? Assessing the Economic Impact of Major League Baseball's All-Star Game. Journal of Sports Economics 2, 307-327.

Baade, R.A., Matheson, V.A., 2003. Bidding for the Olympics: Fool's Gold? In: Barros, C., Ibrahim, M. (Eds.), Transatlantic Sport, London, Edward Elgar Publishing.

Baade, R.A., Matheson, V.A., 2004. The Quest for the Cup: Assessing the Economic Impact of the World Cup. Regional Studies 38, 343-354. 
Baade, R.A., Sanderson, R.A., 1997. The Employment Effect of Teams and Sports Facilities. In: Noll, R.G., Zimbalist, A. (Eds.), Sports, Jobs, and Taxes. The Economic Impact of Sports Teams and Stadiums, Washington D.C., 92-118.

Bade, F.-J., 1991. Regionale Beschäftigungsprognose 1995 (Regional employment forecast 1995). Bonn.

Bade, F.-J., 1997. Sozialversicherungspflichtig Beschäftigte (Employed persons with mandatory social insurance). Dortmund.

Bertrand, M., Duflo, E., Mullainathan, S., 2004. How Much Should We Trust in Difference-inDifference Estimates? NBER Working Paper 8841, http://www.nber.org/papers/w8841 on 11.09.2006.

Buettner, T., Rincke, J., 2004. Labour Market Effects of Economic Integration - The Impact of Re-Unification in German Border Regions, CESifo Working Paper 1179.

Bundesministerium des Inneren, 2006. Die Welt zu Gast bei Freunden: Bilanz der Bundesregierung zur FIFA Fußball_Weltmeisterschaft 2006 (Federal Ministry of the Interior (2006): The world visiting friends: A Federal Government balance-sheet of the FIFA 2006 World Cup), http://www.bmi.bund.de/Internet/Content/Common/Anlagen/Themen/FussballWM_2006/DatenundFakten/Abschlussbericht_WM2006,templateId=raw,property=public ationFile.pdf/Abschlussbericht_WM2006.pdf on 18.12.2006.

Card, D., Krueger, A.B., 1994. Minimum Wages and Employment: A Case Study of the Fast Food Industry in New Jersey and Pennsylvania. American Economic Review 84 (4), 772793.

Carlino, G., Coulson, N.E., 2004. Compensating Differentials and the social benefits of the NFL. Journal of Urban Economics 56, 25-50.

Coates, D., Humphreys, B.R., 1999. The Growth Effects of Sport Franchises, Stadia, and Arenas. Journal of Policy Analysis and Management, 18, No. 4, 601-624.

Coates, D., Humphreys, B.R., 2000a. The Stadium Gambit and Local Economic Development. Regulation: The Cato Review of Business and Government, 23(2), 15-20.

Coates, D., Humphreys, B.R., 2000b. The Economic Consequences of Professional Sports, Strikes and Lockouts. Southern Economic Journal, 67(3), 737-747.

Coates, D., Humphreys, B.R., 2002. The Economic Impact of Postseason Play in Professional Sports. Journal of Sports Economics 3, 291-299.

Coates, D., Humphreys, B.R., 2003a. The Effect of Professional Sports on Earnings and Employment in the Services and Retail Sectors in US Cities. Regional Science and Urban Economics 33 (2), 175-198.

Coates, D., Humphreys, B.R., 2003b. Professional Sports Facilities, Franchises and Urban Economic Development. Public Finance and Management 3, 335-357.

Crompton, J. L., 1995. Economic Impact Analysis of Sports Facilities and Events: Eleven Sources of Misapplication. Journal of Sports Management 9 (January), 14-35.

Davidson, L., 1999. Choice of a proper methodology to measure quantitative and qualitative effects of the impact of sport. Jeanreaud, C. (Ed.) 1999. The Economic Impact of Sports Events, Neuchatel, Center International d`Etude du Sport, 9-28.

EUROSTAT, 2001. New Cronos Data Base, Luxembourg.

Galster, G., Tatian, P., Pettit, K., 2004. Supportive Housing and Neighborhood Property Value Externalities. Land Economics 80 (1), 33-54. 
Goodman, R., Stern, R., 1994. Chicago Hosts Opening Game of World Cup, Illinois Parks and Recreation. 25, No. 3, May/June 1994.

Grant, T., Kessel, Feinstein, 2003. Economic Impact of the SA 2010 FIFA World Cup, Executive Summary, http://www.polity.org.za/pdf/WorldCup2010.pdf on 17.10.2006.

Hagn, F., W. Maennig, 2007. Labour market effects of the 2006 Soccer World Cup in Germany. Hamburg Working Paper Series in Economic Policy Nr. 8/ 2007.

Heyne, M., Maennig, W., Suessmuth, B., 2007. Experience goods and biases in CVM - The case of Soccer WC 2006. Unpublished Paper Bremen University, University of Technology Munich and Hamburg University.

Hotchkiss, J., Moore, R.E., et al., 2003. Impact of the 1996 Summer Olympic Games on Employment and Wages in Georgia. Southern Economic Journal 69, 691-704.

Jeanreaud, C. (Ed.) 1999. The Economic Impact of Sports Events, Neuchatel, Center International d`Etude du Sport.

Kang, Y.S., Perdue, R., 1994. Long-term impacts of a mega-event on international tourism to the host country: a conceptual model and the case of the 1988 Seoul Olympics. Uysal M. (Ed.), Global Tourism Behaviour, New York: International Business Press, 205-255.

Kesenne, S., 1999. Miscalculations and Misinterpretations in Economic Impact Analysis. Jeanreaud, C. (Ed.), 1999. The Economic Impact of Sports Events, Neuchatel, Center International d`Etude du Sport, 29-40.

Khoza, I., 2000. World Cup Bid Speech, South African Football Association, http://www.safa.org.za/html/bid_news.html on 2.7.2002.

Kim, H.J., Gursoy, D., et al., 2006. The impact of the 2002 World Cup on South Korea: Comparison of pre- and post-games. Journal of Tourism Management 27, 86-96.

Kim, S.S., Patrick, J. F., 2005. Residents' perceptions on impacts of the FIFA 2002 World Cup: the case of Seoul as a host city. Tourism Management 26, 25-38.

Noll, R.G., Zimbalist, A. (Eds.), 1997. Sports, Jobs, and Taxes. The Economic Impact of Sports Teams and Stadiums, Washington, D.C.

Rahmann, B., et al., 1997. Sozio-ökonomische Analyse der Fußball-Weltmeisterschaft 2006 in Deutschland (Socio-economic analysis of the Football World Cup 2006 in Germany). Paderborn.

Ritchie, J.R.B., Yangzhou, J., 1987. The Role and Impact of Mega-Events and Attractions on National and Regional Tourism: A Conceptual and Methodological Overview. Paper for 37th AIST Congress, Association Internationale d'Experts Scientifiques du Tourisme, August, Calgary. .

Statistisches Bundesamt (various years Fachserie C, Arbeitsstättenzählung (Thematic Series C, Workplace census), Stuttgart et al.

Statistisches Bundesamt, 2007a. Erwerbspersonen und Erwerbstätige nach Geschlecht (Employed and self-employed persons according to sex), http://www.destatis.de/indicators/d/lrerw01ad.htm on 27.01.2007.

Statistisches Bundesamt, 2007b. Bruttoinlandsprodukt, Bruttonationaleinkommen, Volkseinkommen (Gross domestic product, gross national income, national income), http://www.destatis.de/themen/d/thm_volksw.php on 27.01.2007.

Statistisches Bundesamt, 2007c. Durchschnittliche Bruttomonatsverdienste der Arbeiter/-innen im Produzierenden Gewerbe (Average gross monthly earnings of workers in manufacturing industry), http://www.destatis.de/indicators/d/lrver03ad.htm on 27.01.2007. 
Statistische Bundesamt, 2007d. Preisindizes für die Lebenshaltung und Index der Einzelhandelspreise (Price indices for the cost of living and index of retail trade prices), http://www.destatis.de/themen/d/thm_preise.php on 27.01.2007.

Szymanski, S., 2002. The economic Impact of the World Cup. World Economics 3(1), 169-177.

Teigland, J., 1999. Mega-Events and Impacts on Tourism: The Predictions and Realities of the Lillehammer Olympics, in Impact assessment and project appraisal, 17, 305-317.

Tu, C.C., 2005. How does a new sport stadium affect housing values? The case of FedEx Field. Land Economics 81(3), 379-395. 